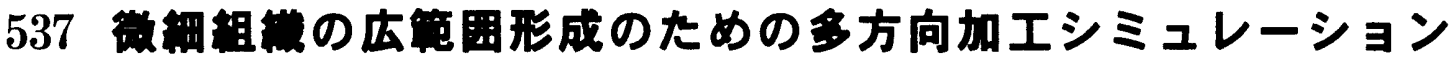

\author{
Simulation of Multi-Directional Deformation for Uniform \\ Formation of Fine Grained Structure
}

$\begin{array}{llll}\text { 正 } & \text { 井上 } & \text { 忠信（金材技研） 非 鳥塚 史郎（金材技研） } \\ \text { 非 長井 } & \text { 寿 }(\text { 金材技研） }\end{array}$

Tadanobu INOUE, National Research Institute for Metals, Sengen 1-2-1, Tsukuba, Ibaraki Shiro TORIZUKA, National Research Institute for Metals

Kotobu NAGAI, National Research Institute for Metals

Key Words : FEM, Uniform Fine Ferrite Structure, Equivalent Plastic Strain, Multi-Directional Deformation

1.はじめに 鉄鋼材料の結晶粒微細化は, 高強 度化, 高勒性化, 高疲労強度化など, 材料の機械的性 質を向上させることが期待できるため, 従来から多く の研究がなされている1,2). それらのいずれの技術も大 きなひずみを材料内に導入することに共通点がある 3),4). 材料内に大ひずみを導入するには, 必然的に大圧 下が要求されるため,これまで微細組織が得られた鋼 材の多くは板厚や線径が薄い場合に限られている.し かし, 実際に構造材料での組織微細化が求められるの は厚肉材や大断面形状の鋼材であり，微細化域を広範 囲化させる技術が求められている5).

厚肉材での微細組織創製が難しいのは, 板厚を確 保した塑性加工の制限の中で大きなひずみを広範囲 な領域に導入することである，著者らは，これまで 加工オー不仆からの相変態において，0.1から4.2に至 る広範な相当塑性ひずみ $\varepsilon_{c q}$ (以後, 塑性ひずみと呼 ぶ）と結晶粒径の関係についての検討を行ってきた 6),7). その結果, 2 以上の塑性ひずみ $\varepsilon_{\text {eq(cri). }}$ になると粒 径は変化しなくなることがわかった.よって，2以 上の塑性ひずみを材料の全領域に導入できれば，微 細組織を均一に得ることが可能となる. そこで, 本 論文では板厚を確保しつつ, 大きな塑性ひずみを広 範囲に分布させる方法として多方向加工を提案し, 多方向加工による広範囲な微細組織の均一形成を数 值解析, 実験の両面から検討した結果について紹介 する.

2. 解析方法 Fig.1はアンビル用いた2方向加工の 模式図と解析で用いた吙江分割である. まず $y, z$ 方向に 一対のアンビ 怆配置し, $y$ 方向に加工(1st pass)後, 直ち にアンビルを離し, $z$ 方向に配置したアンビルで圧繀(2nd pass) した.ここでは, $y, z$ 方向における圧縮後の試験片厚を それぞれ $L y, L z$ と定義する. 加工によって試験片に導入 されるひずみは, アンビ ルのひずみ速度, 加工温度, 試験 片とアンビ 間の接触条件とそれらの形状に依存する.そ こで，実測に基づいた温度とひずみ速度に依存した応 カーひずみ関係を用いた三次元陽解法動的有限要素解 析を適用した。接触条件は, ひずみ分布の実測結果の 比較から求められた摩擦係数 $\mu=0.15$ のクーロ绦件を採用 した. また, 加工中のア比忊速度はひずみ速度 $1 / \mathrm{s}$ と して制御した. 材料は, 0.16C-04Si-1.43Mn鋼を対象とし た.

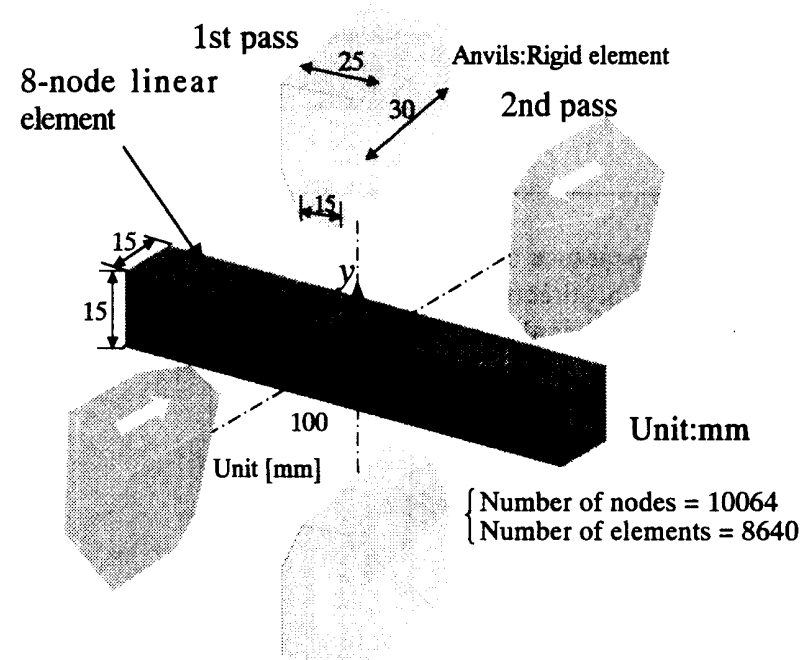

Fig. 1 Schematic illustration of bi-directional compression

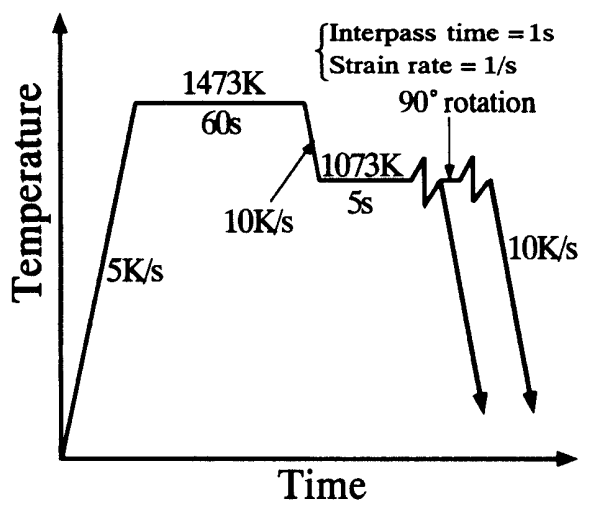

Fig. 2 Thermo-mechanical treatment condition of uni- and bidirectional compression

3. 英験方法 実験は, 多方向圧縮型加工熱処理シ ミュレータ8)を用い, 試験片およびアンビルの形状と寸法は Fig.1に示したとおりである. 加工熱処理条件をFig.2に 示す. 温度 $1473 \mathrm{~K}$ で $60 \mathrm{~s}$ 保持後 (そのとき初期オー对ナイト 粒径 $\left.d_{y}=300 \mu \mathrm{m}\right), 1073 \mathrm{~K}$ まで冷却し, $5 \mathrm{~s}$ 保持後直ちに ひずみ速度 $1 / \mathrm{s}$ で圧縮される. 1 方向加工の場合, $y$ 方 向に圧縮後 $10 \mathrm{~K} / \mathrm{s}$ で冷却した. 2 方向加工の場合, まず $y$ 方向に圧縮(1st pass)後, $90^{\circ}$ 回転し, $z$ 方向に圧縮 (2nd pass)後, $10 \mathrm{~K} / \mathrm{s}$ で泠却した. このとき, パス間時間は $1 \mathrm{~s}$ である. 各加工の場合ともに, 加工後の泠却中に起こ る相変態によって,オー不ナ仆 $(\gamma)$ 組織はつエう仆 $(\alpha)$ 組織 に変化する.

〔No.00-17〕日本機械学会第 13 回計算力学講演会講演論文集〔2000-11.28 30・豊橋市〕 
(a)

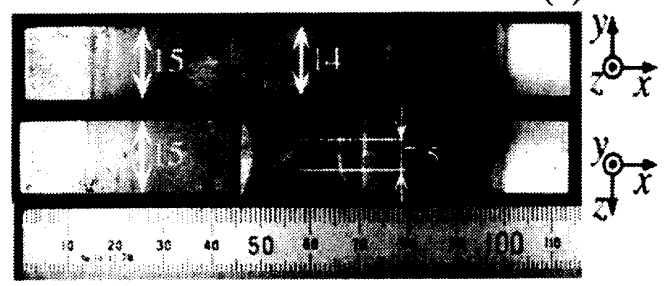

(b)

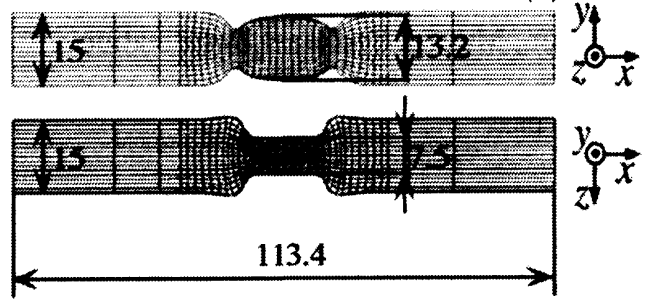

Fig. 3 (a) Appearance of the specimen compressed to $L y: 7.5 \rightarrow L z: 7.5$ bi-directionally and $(b)$ deformed mesh obtained by the FE-analysis.
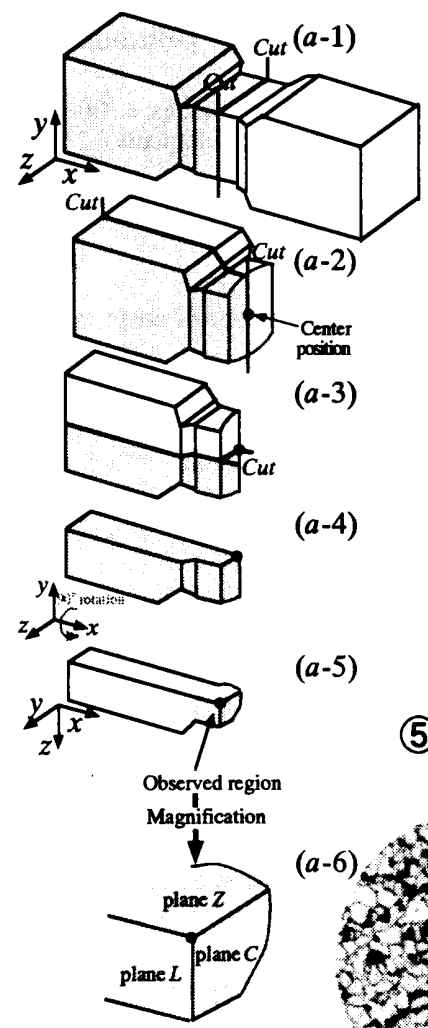

$(a-4)$

$(a-5)$

(5)

$\varepsilon=1.97$
$d_{\alpha}=4.0 \mu \mathrm{m}$

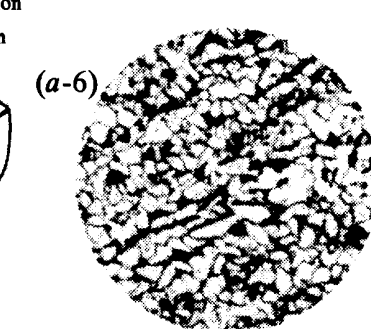

(3)

$$
\begin{aligned}
& \varepsilon=2.14 \\
& d_{\alpha}=3.8 \mu \mathrm{m}
\end{aligned}
$$

(1) $\varepsilon=1.31$

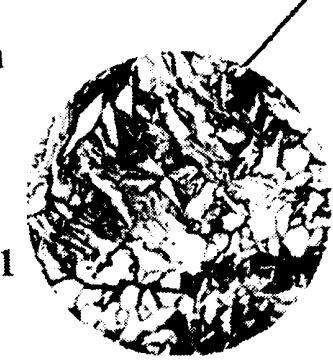

\section{4. 結果と検討}

2方向加工 ( $L y: 7.5 \rightarrow L z: 7.5)$ における, 加工後の試験片の形状を 解析で得られた変形図とともにFig.3に示す.この図から, 実験と 解析で得られた加工後の形状が一致していることがわかる.

Fig.4は，2 方向加工（Ly:7.5 $\rightarrow L z: 7.5 ）$ に対して解析から得られ た塑性ひずみのコ㶤-図と組織の三次元写真をそれぞれ示す。同時 に, 幾つかの位置において拡大した組織写真と直線切断法によっ て測定された $\alpha$ の平均結晶粒径 $d_{\alpha}$ ，そしてその位置における塑性 ひずみ $\varepsilon$ の値も表示する. Fig.4から, 板厚のほほ半分がポリゴナ ル $\alpha$ になっているのがわかる. そのとき， $\alpha$ の結晶粒径は塑性ひ ずみの值 $\left(1.97 \leq \varepsilon_{e q} \leq 2.64\right)$ にかかわらずほとんど一定である.この 均一な微細組織が占める領域は，Fig.4(b)に示した 2.0 以上の塑性 ひずみの領域に一致している. すなわち, 前述したこれまでの結 晶粒径と塑性ひずみの関係結果からわかるように, 臨界值となる 2以上の塑性ひずみを材料内に導入することができれば,たとえひ ずみ分布があっても, 微細な均一 $\alpha$ 組織が広範囲に得られること がわかる.

\section{考文献 省略}

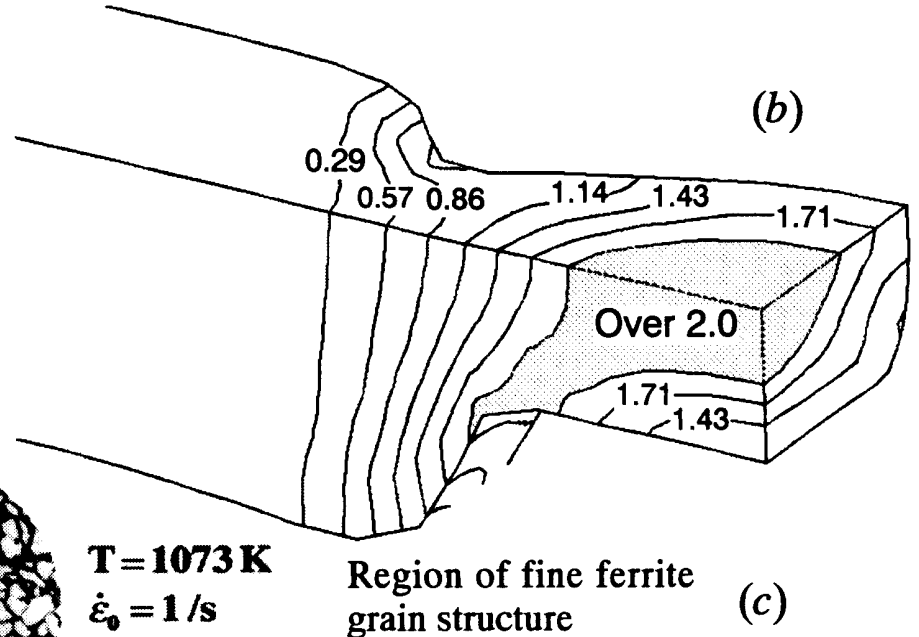
grain structure

(c) 